\title{
ASSESSMENT OF ICT USAGE AMONG SECONDARY SCHOOL COMPUTER TEACHERS AND STUDENTS IN NSUKKA EDUCATION ZONE OF ENUGU STATE, NIGERIA
}

\author{
Ugochi Ugwu ${ }^{1 *}$, Samuel Okeke ${ }^{2}$ \\ ${ }^{1}$ The College of Education Nsukka, Nigeria \\ ${ }^{2}$ Nnamdi Azikiwe University Awka, Nigeria
}

\begin{abstract}
The use of Information and Communication Technology (ICT) is very essential in the spread of information. Electronic devices and softwares which aid the spread of information constitute ICT. These devices have impacted positively in education through lesson preparation, instructional delivery, individualized instruction, and collaborative learning. Despite the positive roles of ICT in education, there is paucity of information on its use by secondary school computer teachers and students in Nigeria. The study was thus designed to assess ICT usage among secondary school computer teachers and students in Nsukka Education Zone. The study population consisted of 51 computer teachers and 4242 students while the sample size comprised of 51computer teachers and 520 students. A survey research design was adopted for the study. Data was collected using an instrument titled 'ICT Usage Assessment Questionnaire' validated by three experts in computer education. Data were presented as frequencies and percentages. The results of the study showed that ICT was not used effectively in lesson preparation, instructional delivery, individualized learning and collaborative learning of computer studies in public secondary schools in the Zone. Based on the findings, it was concluded that Nigerian secondary schools are yet to extensively adopt Information and Communication Technology.
\end{abstract}

Keywords: Computer studies, ICT, Nsukka, Students, Teachers

\section{Introduction}

Information and Communication Technology is an umbrella that includes any communication device, or application including radio, television, cellular phones, computer, and network's hardware and software, satellite systems as well as the various associated services and applications notably, video conferencing and distance learning (Offor, 2012). Cited benefits of ICT can be seen in nearly every sector of the economy including e-banking and e-learning (Daniel et al., 2007). Ayogu (2010) also opined that ICT is often spoken of in terms of a particular context like: ICT in home, health care, library and of course education, the main focus of this study.

According to Mba (2007), ICT in education simply means using ICT to teach and learn. ICT has been used to empower the teachers of computer studies and to promote the growth of skills necessary for the $21^{\text {st }}$ century workplace (Ogumadu, 2006). Hence, uses of ICT in education can be summarized into lesson preparation, instructional delivery, individualized learning and collaborative learning (Nwosu, 2013).

The inability of many secondary school graduates to make adequate use of Information and Communication Technology (ICT) devices has become worrisome to the educational system of Nigeria. It is evident that despite the policies on ICT in education; computer studies being made compulsory in West African Examination Council; knowledge of computer being a prerequisite for most jobs and Joint Admissions and Matriculation Board examination being made computer based, there is still a high level of computer illiteracy among secondary school graduates especially those that graduated from public schools. 
Factors responsible for this inadequate use of ICT in Nigerian education sector include lack of adequate ICT facilities and scarcity of qualified computer teachers (Adomi and Kpangban, 2010). Many public secondary schools lack basic ICT facilities such as computer laboratory, computers, projectors, tablets, electricity, stand-by generating set, internet connection and qualified computer teachers. Students are therefore exposed to computer studies theoretically with little or no hands-on training. Stressing these challenges further, Yusuf in his analysis of the 'Nigerian National Policy for Information Technology', noted that this policy was inadequate for positive impact on the Nigerian education system (Yusuf, 2005). This is because the philosophical frame of reference seems to be market driven with little emphasis on the integration of ICT in instruction (Yusuf, 2005). Additionally, Nwidum (2010) also noted that ICT appeared to be more workable in such field as engineering and medicine in Nigeria than in education (Nwidum, 2010). This researcher also emphasized that the use of projector in teaching secondary school students in rural areas is impossible due to lack of a well-articulated education policy and electricity (Nwidum, 2010).

The study therefore focuses on the need to ascertain the usage of ICT among secondary school Computer Studies Teachers and Students using Nsukka Education Zone of Enugu State as a model. The study specifically sought to assess teachers' usage of ICT in lesson preparation for computer studies, teachers' usage of ICT in instructional delivery of computer studies, students' usage of ICT in individualized learning of computer studies and students' usage of ICT in collaborative learning of computer studies.

\section{Research questions}

The following research questions were raised to guide the study:

1. What is the computer teachers' level of agreement on ICT usage in lesson preparation for computer studies in secondary schools in Nsukka Education Zone of Enugu State?

2. What is the computer teachers' level of agreement on ICT usage in instructional delivery of computer studies in secondary schools in Nsukka Education Zone of Enugu State?

3. What is the students' level of agreement on ICT usage in individualized learning of computer studies in secondary schools in Nsukka Education Zone of Enugu State?

4. What is the students' level of agreement on ICT usage in collaborative learning of computer studies in secondary schools in Nsukka Education Zone of Enugu State?

\section{Methodology}

Descriptive survey research design as described by Ezeah (2011) was adopted for this study. The study population comprised of 4242 Senior Secondary Three (SS3) students and 51 computer teachers obtained from the 64 public secondary schools within Nsukka Education Zone of Enugu State. Stratified and proportionate purposive random sampling methods were used to obtain a sample size of 520 student-respondents and 51 Computer studies teacher-respondents from 34 secondary schools (23 urban and 11 rural schools).

Instrument for data collection was a self-designed structured questionnaire titled 'ICT Usage Assessment Questionnaire (ICTUAQ)' validated by three computer education experts. The Cronbach Alpha was used to determine the reliability of the instrument and the reliability was 0.85 . the questionnaire was administered by the researchers with the help of research assistants.

Data analysis: Data collected were analyzed using frequency tables and percentage scores. 


\section{Results}

The results of the study are presented below.

Research question 1: What is the computer teachers' level of agreement on ICT usage in lesson preparation for computer studies in secondary schools in Nsukka Education Zone of Enugu State?

Data presented in Table 1 shows that items 1, 2, 5 and 7 were used by computer teachers in lesson preparation of computer studies while items 3, 4, 6, 8 and 9 were not used.

Research question 2: What is the computer teachers' level of agreement on ICT usage in instructional delivery of computer studies in secondary schools in Nsukka Education Zone of Enugu State?

Data presented in Table 2 shows that items 1-10 were not used by teachers in instructional delivery of computer studies.

Research question 3: What is the students' level of agreement on ICT usage in individualized learning of computer studies in secondary schools in Nsukka Education Zone of Enugu State?

Data presented in Table 3 shows that items 1-10 were not used by students in individualized learning of computer studies.

Research question 4: What is the students' level of agreement on ICT usage in collaborative learning of computer studies in secondary schools in Nsukka Education Zone of Enugu State?

Data presented in Table 4 shows that none of the items (1-10) were used by students in collaborative learning of computer studies.

\section{Discussion}

The results of the assessment of computer teachers' ICT usage in lesson preparation for computer studies revealed that computer teachers' use of ICT in lesson preparation are in sourcing lesson materials with computer or phone and saving these materials in computer storage devices only. These findings are in agreement with the report of Ezema (2010) which stated that many computer teachers in secondary schools only make use of ICT to source lesson materials in preparation for teaching.

The percentage responses of the assessment of computer teachers' use of ICT in instructional delivery of computer studies implied that ICT was not incorporated in instructional delivery of computer studies in secondary schools in Nsukka Education Zone of Enugu State. This finding agrees is in line with the opinion of Adomi and Kpangban (2010) that many secondary schools, especially the public ones lack basic ICT facilities, making it difficult for teachers to use ICT to carry out teaching.

The study also showed that secondary school students in Nsukka Education Zone of Enugu State do not make use of ICT in individualized learning of computer. This could be attributed to the absence of ICT tools necessary to carry out individualized learning (Angib, 2005).

The result of the assessment of students' use of ICT in collaborative learning of computer studies suggests that students do not also make use of ICT in collaborative learning of computer studies in public secondary schools in Nsukka Education Zone of Enugu State. This finding is similar with the report of Kaplan (2008) which stated that despite the fact that ICT promotes a virtual collaboration among students which is focused on addressing a specific area, students do not engage in it to study together. 


\section{Conclusion and Recommendations}

The results of this study have shown that ICT is not effectively used in lesson preparation, instructional delivery, individualized learning and collaborative learning among secondary school computer studies Teachers and Students in Nsukka Education Zone of Enugu State. Based on the findings, it was concluded that ICT is not used effectively by teachers and students in Nsukka Education Zone of Enugu State.

It is recommended that adequate number of competent computer teacher(s) be employed in each public secondary school in Nsukka Education Zone of Enugu State; urgent ICT training workshop for already recruited computer teachers be carried out and adequate ICT facilities needed for proper use of ICT in teaching and learning be provided.

\section{References}

Adomi, E. E. \& Kpangban, E. (2010). Application of ICTs in Nigerian Secondary Schools. Library Philosophy and Practice. Retrieved from http://www.webpages.uidaho.edu/mbolin/adomi-kpangban.html

Angib, M. U. (2005). The Family as a Supportive Agent on Computer Education of a Nigerian Child. Retrieved from http://www.bikeweb.com>home

Ayogu, B. U. (2010). The Internet: A Gateway to Technical Education. Onitsha: OSAMS Publishers.

Daniel, E. E. et al. (2007). ICT Integration in Education. Journal of Information and Technology Impact, 7(3), 181-194

Ezeah, E. N. (2011). Effective Utilization of ICT in Teaching and Learning of Computer studies in Colleges of Education in South East Geopolitical Zone of Nigeria. An Unpublished M.Sc. Thesis, Department of Vocational Teachers Education, University of Nigeria Nsukka.

Ezema, S. C. (2010). ICT in Teaching and Learning. Journal of Computer Assisted Learning, 20(6), 456-470

Kaplan, S. (2008). Strategies for Collaborative Learning. Retrieved on 7th March 2008 from http://www./coher/collaborativelearning.htm

Mba, S. O. (2007). The Use of ICT as an Instructional Technique. Nsukka: Paulingo Publishers.

Nwidum, F. (2010). Weakness of ICT in the Imparting of Knowledge and Educational Inquiry. International Journal of Research in Education, 6(1\&2), 185-192.

Nwosu, E. F. (2013). Strategies for Effective Implementation of ICT in Nigerian Secondary

Education in Obollo Education Zone of Enugu State. An Unpublished M.Sc. Thesis, Department of Vocational Teachers Education, University of Nigeria Nsukka.

Offor, K. N. (2012). Implementing the Techniques of ICT in a Sociological Society. Lagos: Keystone Publishers.

Ogunmadu, H. C. (2006). The Influence of ICT on Teacher Education and Professional Development in Abia State. An Unpublished M.Sc. Thesis, Department of Vocational Teachers Education, University of Nigeria Nsukka.

Yusuf, M.O. (2005). An Investigation into Teachers' Competence in Implementing Computer studies in Nigeria secondary schools. Journal of Science Teaching and Learning, 3(1 \& 2), 54-63. 


\section{Appendix}

Table 1: Assessment of Computer Teachers' ICT Usage in Lesson Preparation for Computer Studies

\begin{tabular}{|c|c|c|c|c|c|c|}
\hline \multirow{2}{*}{$\begin{array}{l}\text { Item Statements } \\
\text { As a computer teacher in secondary } \\
\text { school, I make use of: }\end{array}$} & \multicolumn{4}{|c|}{$\begin{array}{l}\text { Frequency of } \\
\text { Responses }\end{array}$} & \multirow[t]{2}{*}{$\begin{array}{l}\text { Percentages } \\
\%\end{array}$} & \multirow[t]{2}{*}{ Decision } \\
\hline & SA & A & D & SD & & \\
\hline $\begin{array}{l}\text { 1. Computer and cell phones in } \\
\text { sourcing for lesson materials in } \\
\text { preparation for my lessons }\end{array}$ & 30 & 13 & 7 & 0 & 91.90 & A \\
\hline $\begin{array}{l}\text { 2. The internet to update my } \\
\text { knowledge for preparation of } \\
\text { my lesson note }\end{array}$ & 20 & 10 & 10 & 10 & 78.57 & A \\
\hline $\begin{array}{l}\text { 3. The internet to discover new } \\
\text { knowledge pattern for my } \\
\text { lesson preparations }\end{array}$ & 0 & 8 & 12 & 30 & 30.76 & $\mathrm{D}$ \\
\hline $\begin{array}{l}\text { 4. ICT facilities like computer and } \\
\text { presentation software to } \\
\text { organize my lesson materials in } \\
\text { readiness for teaching }\end{array}$ & 0 & 0 & 17 & 33 & 00.00 & $\mathrm{D}$ \\
\hline $\begin{array}{l}\text { 5. The internet to gather learning } \\
\text { experiences required for } \\
\text { teaching }\end{array}$ & 5 & 15 & 18 & 12 & 57.52 & A \\
\hline $\begin{array}{l}\text { 6. The internet for Computer } \\
\text { Assisted Instructions that will } \\
\text { help to enhance my teaching }\end{array}$ & 0 & 0 & 31 & 19 & 00.00 & $\mathrm{D}$ \\
\hline $\begin{array}{l}\text { 7. Computer storage devices to } \\
\text { save documents in readiness for } \\
\text { teaching }\end{array}$ & 21 & 16 & 9 & 4 & 85.71 & A \\
\hline $\begin{array}{l}\text { 8. Computer programs to develop } \\
\text { CAIs to aid my teaching }\end{array}$ & 0 & 0 & 35 & 15 & 00.00 & D \\
\hline $\begin{array}{l}\text { 9. PowerPoint computer slides to } \\
\text { prepare my lesson before } \\
\text { presentation }\end{array}$ & 5 & 8 & 27 & 10 & 40.74 & $\mathrm{D}$ \\
\hline
\end{tabular}


Table 2: Assessment of Computer Teachers' Use of ICT in Instructional Delivery of Computer Studies

\begin{tabular}{llllcc}
\hline Item Statements As a computer & Frequency & of & Percentages & Decision \\
teacher in secondary school, I make & Responses & & $\%$ \\
use of: & SA A & D & SD & &
\end{tabular}

1. Multimedia projector to deliver $\begin{array}{lllllll}0 & 0 & 18 & 32 & 00.00 & \text { D }\end{array}$ my lessons in the school

2. Computer Assisted Instructions $\begin{array}{lllllll}0 & 3 & 17 & 30 & 12.33 & \text { D }\end{array}$ to deliver my lessons in the school

$\begin{array}{llllllll}\text { 3. The internet to post information } & 0 & 0 & 36 & 14 & 00.00 & \mathrm{D}\end{array}$ to the students of my class

4. Video conferencing to deliver $\begin{array}{lllllll}0 & 0 & 26 & 24 & 00.00 & \text { D }\end{array}$ my lessons

5. Online methods like e-Learning $\begin{array}{lllllll}0 & 0 & 14 & 36 & 00.00 & \text { D }\end{array}$ to deliver my lessons

6. Tutorial packages on CD ROMs $\begin{array}{lllllll} & 0 & 5 & 22 & 23 & 18.29 & \text { D }\end{array}$ to teach and assess my students

$\begin{array}{lllllllll}\text { 7. The internet to hold virtual } & 0 & 0 & 13 & 37 & 00.00 & \mathrm{D}\end{array}$ classes with students of my class and my colleagues

$\begin{array}{llllllll}\text { 8. The internet to access bulletin } & 0 & 8 & 11 & 31 & 31.17 & \text { D }\end{array}$ boards available on the web that provide discussion forums for instructional delivery of my lessons

9. Teleconferencing to deliver my $\begin{array}{lllllll}0 & 0 & 21 & 29 & 00.00 & \text { D }\end{array}$ lesson

10. Smart board to deliver my $\begin{array}{lllllll}0 & 0 & 10 & 40 & 00.00 & \text { D }\end{array}$ lesson 
Table 3: Assessment of Students' Use of ICT in Individualized Learning of Computer Studies

\begin{tabular}{|c|c|c|c|c|c|c|}
\hline \multirow{2}{*}{$\begin{array}{l}\text { Item Statements } \\
\text { As a student in secondary school, I } \\
\text { make use of: }\end{array}$} & \multicolumn{4}{|c|}{$\begin{array}{l}\text { Frequency of } \\
\text { Responses }\end{array}$} & \multirow[t]{2}{*}{$\begin{array}{c}\text { Percentages } \\
\%\end{array}$} & \multirow[t]{2}{*}{ Decision } \\
\hline & SA & $\mathbf{A}$ & D & SD & & \\
\hline $\begin{array}{l}\text { 1. Internet to access options } \\
\text { available in the net for web } \\
\text { based learning in my school }\end{array}$ & 0 & 0 & 350 & 150 & 00.00 & $\mathrm{D}$ \\
\hline $\begin{array}{l}\text { 2. The internet to explore } \\
\text { different learning options at } \\
\text { my own pace }\end{array}$ & 0 & 0 & 325 & 175 & 00.00 & $\mathrm{D}$ \\
\hline 3. CAI to learn in my school & 0 & 43 & 227 & 230 & 15.87 & $\mathrm{D}$ \\
\hline $\begin{array}{l}\text { 4. The internet to improve } \\
\text { learning focus and self } \\
\text { directed learning very well in } \\
\text { my school }\end{array}$ & 0 & 0 & 378 & 122 & 00.00 & $\mathrm{D}$ \\
\hline $\begin{array}{l}\text { 5. The computer laboratory to } \\
\text { discover and explore things on } \\
\text { my own }\end{array}$ & 0 & 93 & 250 & 157 & 29.81 & $\mathrm{D}$ \\
\hline $\begin{array}{l}\text { 6. The internet to download } \\
\text { beneficial learning materials }\end{array}$ & 0 & 0 & 421 & 79 & 00.00 & $\mathrm{D}$ \\
\hline $\begin{array}{l}\text { 7. Online learning resources on } \\
\text { at least one of the following: } \\
\text { desktop computer, laptop } \\
\text { computer, cell/mobile phone } \\
\text { with mp } 3 \text { capability }\end{array}$ & 0 & 86 & 351 & 63 & 25.22 & $\mathrm{D}$ \\
\hline $\begin{array}{l}\text { 8. Electronic digital ICT libraries } \\
\text { to read up materials on } \\
\text { Computer studies }\end{array}$ & 0 & 112 & 298 & 90 & 32.88 & $\mathrm{D}$ \\
\hline $\begin{array}{l}\text { 9. Computer storage device }(\mathrm{s}) \text { to } \\
\text { save downloaded materials }\end{array}$ & 0 & 143 & 266 & 91 & 40.78 & D \\
\hline $\begin{array}{l}\text { 10. ICT facilities like cell phone } \\
\text { and tablets to have a virtual } \\
\text { classroom learning at any time } \\
\text { and place }\end{array}$ & 0 & 157 & 280 & 63 & 43.05 & $\mathrm{D}$ \\
\hline
\end{tabular}


Proceeding of the $4^{\text {th }}$ International Conference on Education, Vol. 4, Issue 2, 2018, pp. 46-53

Table 4: Assessment of Students' Use of ICT in Collaborative Learning of Computer Studies

\begin{tabular}{lllllllll}
\hline Item Statements & \multicolumn{5}{c}{$\begin{array}{c}\text { Frequency of } \\
\text { Responses }\end{array}$} & & Percentages & Decision \\
As a student in secondary school, I \\
make use:
\end{tabular}

